\title{
Mentors as Female Role Models in STEM Disciplines and Their Benefits
}

\author{
Sulema Torres-Ramos (), Nicte Selene Fajardo-Robledo, Lourdes Adriana Pérez-Carrillo (1), \\ Claudia Castillo-Cruz ${ }^{(0)}$, Patricia del R. Retamoza-Vega ${ }^{(D}$, Verónica M. Rodríguez-Betancourtt \\ and Cristina Neri-Cortés *(1)
}

check for updates

Citation: Torres-Ramos, S.; FajardoRobledo, N.S.; Pérez-Carrillo, L.A.; Castillo-Cruz, C.; Retamoza-Vega, P.d.R.; Rodríguez-Betancourtt, V.M.; Neri-Cortés, C. Mentors as Female Role Models in STEM Disciplines and Their Benefits. Sustainability 2021, 13, 12938. https://doi.org/10.3390/ su132312938

\section{Academic Editors: Carina}

Soledad González-González,

Alicia García-Holgado and

Rebecca Strachan

Received: 31 October 2021

Accepted: 21 November 2021

Published: 23 November 2021

Publisher's Note: MDPI stays neutral with regard to jurisdictional claims in published maps and institutional affiliations.

Copyright: (c) 2021 by the authors. Licensee MDPI, Basel, Switzerland. This article is an open access article distributed under the terms and conditions of the Creative Commons Attribution (CC BY) license (https:/ / creativecommons.org/licenses/by/ $4.0 /)$.
University Center of Exact Sciences and Engineering (CUCEI), University of Guadalajara (UdG), Guadalajara 44100, Jalisco, Mexico; sulema.torres@academicos.udg.mx (S.T.-R.); nicte.fajardo@academicos.udg.mx (N.S.F.-R.); lourdes.pcarrillo@academicos.udg.mx (L.A.P.-C.); claudia.ccruz@academicos.udg.mx (C.C.-C.); patricia.retamoza@academicos.udg.mx (P.d.R.R.-V.); veronica.rbetancourtt@academicos.udg.mx (V.M.R.-B.)

* Correspondence: cristina.neri@academicos.udg.mx

\begin{abstract}
Several studies have addressed the benefits of mentoring from the mentor's perspective, especially those related to soft skills. However, to the best of our knowledge, there are no studies that either relate the mentoring in STEM areas with female role models or that analyze them from a data-mining perspective. In this work, a questionnaire was elaborated to address the mentor's benefits related to soft skills and technical knowledge; afterward, a data-mining methodology was used to analyze the mentor's perceptions related to female role models and STEM reinforcement. In addition, sentiment analysis was performed in order to determine the emotional polarity in the text used by the mentors to describe their mentoring experience. The results show that soft and technical skills are acquired by the mentors, and participating in mentoring programs allows them to perceive themselves as female role models. Additionally, by using decision trees, it was possible to determine the mentors' characteristics that perceive a STEM reinforcement or that produce attraction. In addition, the results show that the general perception of the mentors' experience was positive. Finally, the use of machine learning techniques, specifically data mining and sentiment analysis, allowed us to both confirm the results obtained in a qualitative way and to obtain new interesting results.
\end{abstract}

Keywords: mentoring; STEM; higher education; female role model; gender gap; equity; data mining

\section{Introduction}

According to the University of Reading [1], the mentoring objective is to support and encourage people to be able to manage their learning so that they may maximize their potential, develop their skills, improve their performance, and become the person they intend to be. Mentoring definition and conceptualization are elements that have been addressed by several authors. According to Sands et al. [2], some key factors are: friendship, career guidance, information source, and intellectual guidance. Additionally, Sambunjak et al. [3] concluded that mentorship has an "important influence on personal development, career guidance, career choice, and productivity"; this conclusion is likewise supported by Farrell et al. [4] and Beltman and Schaeben [5].

There are different types of mentoring, and, based on [6], contemporary mentoring can be classified into nine types: formal mentoring, informal mentoring, diverse mentoring, electronic mentoring, co-mentoring/collaborative mentoring, group mentoring, peer mentoring, multilevel mentoring structure, and cultural mentoring. In this sense, Mullen and Klimaitis [6] defined formal mentoring as a planned, structured, and intentional interaction that targets gaps and resolves problems in programs and organizations, while informal mentoring ignites when mentors and their mentees meet naturally. Cross-gender 
and cross-race mentoring are formations that join mentor and mentee who differ demographically and is also known as diverse mentoring. In addition, electronic mentoring has arisen due to technology's growth, and it mediates learning and communication remotely through social media, cloud-based/online platforms, synchronous chats, and email. Comentoring/collaborative mentoring unites individuals in a mutually beneficial relationship where mentor and mentee might evolve into co-mentors, or they might start out as peers. In group mentoring, three or more people challenge and support one another's growth, and they may mentor across differences. Peer mentoring involves developmental learning that can be informal or formal; it attracts those who are new to a particular experience or event and those who have lived through it. The relationship context is an activity-based learning environment that typically involves rigorous programs like STEM. The relationship fosters engagement, collaboration, communication, support, and risk taking without the hierarchical element. For the case of multilevel mentoring, this refers to mentoring across organizational levels. Finally, cross-cultural relationships within diverse environments are nurtured by cultural mentoring.

On the other hand, the benefit of mentoring is clearly recognized in numerous sources, and mentoring is considered as a mutually beneficial relationship that provides mentees and mentors with benefits that span from personal satisfaction to career advancement [7-9].

Additionally, mentoring has been recognized as an influential mechanism in the professional development of the mentee-commonly related to the mentor's identitywho sees the mentor as a role model, which in turn is a factor that has been identified and associated with successful professional development [10]. The role model in mentoring has been defined by Gibson as a construct based on attributes of people with social roles that an individual perceives as similar to himself, where he wishes to increase his similarity by emulating those attributes. About the role model and career stage, Gibson also found that in the early career-acquisition stage, individuals work on a viable self-concept emulating others, using positive, close role models and a range of attributes in the construction of the professional identity [11].

For this reason, "role models" are often seen as one of the most promising avenues to reduce the gender gap in science, technology, engineering, and mathematics (STEM) areas [12], because individuals seek others with some similarities; they are informative for making accurate self-assessments and can be inspirational for self-improvement [13]. For example, in an organizational context, if women do not see other women in high positions, they may perceive that there is no one to emulate. This is why in mentoring programs, such as Technovation Girls [14] where young women mentors guide teams formed of younger women to solve a problem in their community using a mobile application, it is crucial that the role model is represented by and for young women.

Several studies have identified the mentoring benefits in mentees and how female mentors help to improve the mentees' academic achievement and enrollment in STEM [15,16]. However, only a few studies address the mentoring benefits from the mentor's perspective and how this mentoring process allows them to perceive themselves as female role models, as well as their STEM engagement.

Therefore, the present study addresses the premise that a mentor can become a female role model and that mentoring can reinforce her vocation in STEM areas or bring her close to them. In addition, the analysis was performed by using data-mining techniques, which are a new approach to address this kind of research, in the context of a formal, peer, and electronic mentoring program.

\section{Materials and Methods}

\subsection{The Mentoring Program}

Based on our hypotheses and in order to analyze the results from a gender perspective, it was decided to perform this study over women who have provided mentoring, specifically, mentors of the Technovation Girls program. 
Technovation Girls [14] is a global program that aims to empower girls to become leaders, creators, and problem-solvers. In this program, girls' teams between 10 to 18 years old choose a problem from their community and propose a solution using technology, specifically mobile apps. This is a formal mentoring program where teams are guided by mentors, most of whom are adult women that help with the organization of the proposal in addition to giving feedback and providing encouragement and model persistence, courage, and creativity on a challenging program.

This mentoring program is developed in two ways; in one side, there is a structured program of 12 weeks where mentors and mentees attend weekend workshops on soft and technical skills that are helpful for the accomplishment of their projects, such as design thinking, pitching, business modeling, marketing, programming, databases and artificial intelligence, and video production, among others. Moreover, there are activities and materials scheduled for deliverables achievement.

Considering the world pandemic situation, the last season (2020-2021) training process was implemented in a virtual manner; however, since 2017, the University Center of Exact Sciences and Engineering (CUCEI) had been working on this mentoring program in a face-to-face mode, through the interactive workshops.

On the other side, informal mentoring is also applied during the week when the mentor and the mentees work on their project; in this regard, the amount of time and the type of interaction (electronic or face-to-face) is optional and is decided inside of each group.

\subsection{Questionnaire Design}

In order to identify the benefits of mentoring for the persons who provide it, as well as the impact it has on the perception of STEM areas, a survey was conducted among women who provide or have provided mentoring.

The survey consisted of 31 questions divided into 6 sections: general data, soft skills, technical knowledge, role model perception, STEM perception, and general perception. The following section describes the questions developed and their details for each section.

\subsubsection{General Data}

This section included questions for the interviewed about their academic data and general data about their mentoring. It is important to mention that in order to maintain the privacy and confidentiality of the information, no sensitive personal data was collected, such as names or emails. Table 1 shows the questions included in this section as well as the data type and value range.

Table 1. Questions for the survey in the general data section.

\begin{tabular}{|c|c|c|c|}
\hline Id & Question & Data Type & Value \\
\hline 1 & How old are you? & Numeric & $18-60$ \\
\hline 2 & What is your academic degree? & Categorical & $\begin{array}{l}\text { High school, bachelor's, } \\
\text { master's, doctorate }\end{array}$ \\
\hline 3 & What is your career or professional area? & Categorical & Open \\
\hline 4 & How many years have you been a mentor? & Numeric & $1-10$ \\
\hline 5 & $\begin{array}{c}\text { How many hours per week do you dedicate or } \\
\text { did you dedicate to mentoring? }\end{array}$ & Numeric & $1-10$ \\
\hline
\end{tabular}

\subsubsection{Soft Skills}

Several authors mentioned that soft skills are one of the benefits or skills that mentors develop [17-19]. Therefore, to verify the benefit of mentoring in the acquisition of these skills, the questions in Table 2 were included. 
Table 2. Questions for the survey in the soft skills section.

\begin{tabular}{|c|c|c|c|}
\hline Id & Question & Data Type & Value \\
\hline 6 & $\begin{array}{l}\text { What skills do you consider necessary to } \\
\text { develop or improve mentoring? }\end{array}$ & $\begin{array}{l}\text { Categorical: } \\
\text { multiple }\end{array}$ & $\begin{array}{l}\text { Leadership, organization, empathy, } \\
\text { motivation, communication, other }\end{array}$ \\
\hline 7 & $\begin{array}{l}\text { Do you consider that you have acquired or } \\
\text { improved any of these skills by being a mentor? }\end{array}$ & Categorical & Yes, no \\
\hline 8 & $\begin{array}{l}\text { At the beginning of your mentoring, what } \\
\text { leadership level do you consider you had? }\end{array}$ & Categorical & Null, low, average, good, outstanding \\
\hline 9 & $\begin{array}{l}\text { At the beginning of your mentoring, what } \\
\text { organization level do you consider you had? }\end{array}$ & Categorical & Null, low, average, good, outstanding \\
\hline 10 & $\begin{array}{l}\text { At the beginning of your mentoring, what } \\
\text { empathy LEVEL do you consider you had? }\end{array}$ & Categorical & Null, low, average, good, outstanding \\
\hline 11 & $\begin{array}{l}\text { At the beginning of your mentoring, what } \\
\text { motivation level do you consider you had? }\end{array}$ & Categorical & Null, low, average, good, outstanding \\
\hline 12 & $\begin{array}{l}\text { At the beginning of your mentoring, what } \\
\text { communication level do you consider you had? }\end{array}$ & Categorical & Null, low, average, good, outstanding \\
\hline 13 & $\begin{array}{l}\text { At the end of your mentoring, what leadership } \\
\text { level do you consider you had? }\end{array}$ & Categorical & Null, low, average, good, outstanding \\
\hline 14 & $\begin{array}{l}\text { At the end of your mentoring, what organization } \\
\text { level do you consider you had? }\end{array}$ & Categorical & Null, low, average, good, outstanding \\
\hline 15 & $\begin{array}{l}\text { At the end of your mentoring, what empathy } \\
\text { level do you consider you had? }\end{array}$ & Categorical & Null, low, average, good, outstanding \\
\hline 16 & $\begin{array}{l}\text { At the end of your mentoring, what motivation } \\
\text { level do you consider you had? }\end{array}$ & Categorical & Null, low, average, good, outstanding \\
\hline 17 & $\begin{array}{l}\text { At the end of your mentoring, what } \\
\text { communication level do you consider you had? }\end{array}$ & Categorical & Null, low, average, good, outstanding \\
\hline
\end{tabular}

\subsubsection{Technical Knowledge}

To identify whether mentoring provides benefits related to the acquisition of new knowledge or technical skills, Table 3 presents the questions included in the survey related to the topic.

Table 3. Questions for the survey in the technical knowledge section.

\begin{tabular}{cccc}
\hline Id & \multicolumn{1}{c}{ Question } & Data Type & Value \\
\hline 18 & $\begin{array}{c}\text { What expertise do you consider necessary to } \\
\text { perform or improve mentoring? }\end{array}$ & $\begin{array}{c}\text { Categorical: } \\
\text { multiple }\end{array}$ & Open \\
\hline 19 & $\begin{array}{c}\text { Do you consider that you have acquired new } \\
\text { technical knowledge by being a mentor? }\end{array}$ & Categorical & Yes, no \\
\hline 20 & $\begin{array}{c}\text { If you answered yes to the previous question, } \\
\text { what technical knowledge have you acquired? }\end{array}$ & $\begin{array}{c}\text { Categorical: } \\
\text { multiple }\end{array}$ & Open \\
\hline
\end{tabular}

\subsubsection{Role Model Perception}

To analyze the mentors' perception as role models, the following questions (see Table 4) were included in the survey.

\subsubsection{STEM Perception}

In order to analyze the mentors' perception related to their closeness or reinforcement of the STEM areas, the questions in Table 5 were included in the survey. 
Table 4. Questions for the survey in the role model perception section.

\begin{tabular}{|c|c|c|c|}
\hline Id & Question & Data Type & Value \\
\hline 21 & Do you consider yourself a female role model? & Categorical & Yes, no \\
\hline 22 & $\begin{array}{l}\text { If you answered yes to the previous question, why do you consider } \\
\text { yourself a female role model? }\end{array}$ & Categorical & Open \\
\hline 23 & $\begin{array}{l}\text { If you answered no to Question 21, What would you need to } \\
\text { consider yourself a female role model? }\end{array}$ & Categorical & Open \\
\hline
\end{tabular}

Table 5. Questions for the survey in the STEM perception section.

\begin{tabular}{cccc}
\hline Id & Question & Data Type & Value \\
\hline 24 & $\begin{array}{c}\text { If you belong to STEM areas, do you consider that being a mentor } \\
\text { reinforced your vocation in STEM areas? Otherwise, do you } \\
\text { consider that being a mentor brought you closer to the STEM areas? }\end{array}$ & Categorical & Yes, No \\
\hline 25 & If you answered yes to the previous question, specify why. & Categorical & Open \\
\hline
\end{tabular}

\subsubsection{General Perception}

Table 6 shows the questions designed to analyze the interviewee's perception related to their performance as mentor, as well as her experience.

Table 6. Questions for the survey in the general perception section.

\begin{tabular}{|c|c|c|c|}
\hline Id & Question & Data Type & Value \\
\hline 26 & $\begin{array}{l}\text { What skills or strategies do you think worked for you in } \\
\text { your mentoring? }\end{array}$ & $\begin{array}{l}\text { Categorical: } \\
\text { multiple }\end{array}$ & $\begin{array}{l}\text { Commitment, motivation, } \\
\text { organization, communication, other }\end{array}$ \\
\hline 27 & What would you improve about your mentoring? & $\begin{array}{l}\text { Categorical: } \\
\text { multiple }\end{array}$ & $\begin{array}{l}\text { Spending more time, improving } \\
\text { organization, improving } \\
\text { communication, more monitoring, } \\
\text { learn new things, nothing, other }\end{array}$ \\
\hline 28 & Did bring you benefits to being a mentor? & Categorical & Yes, no \\
\hline 29 & $\begin{array}{c}\text { If you answered yes to the previous question, what are } \\
\text { the benefits it has brought you? }\end{array}$ & Categorical & Open \\
\hline 30 & What impact has being a mentor had on your daily life? & Categorical & Open \\
\hline 31 & $\begin{array}{l}\text { Would you like to write a special comment or } \\
\text { observation about your mentoring activity? }\end{array}$ & Categorical & Open \\
\hline
\end{tabular}

\subsection{Data Acquisition}

To collect the information, the survey was implemented using Google Forms. Because CUCEI has been working with this program since 2017 [20], and because we have the contact information of the mentors, the survey was disseminated directly through email, obtaining 43 answers. It is important to mention that most of the mentors that answered the survey participated last season in Technovation Girls; so, the mentoring type performed by them was formal, peer, and electronic.

\subsection{Data Pre-Processing}

In order to carry out the different analyses of this work, and due to the fact that the answer domain of several questions was open, the preprocessing or data cleaning was performed as follow:

\section{Data Cleaning}

The data cleaning was achieved by capitalization treatment, punctuation marks elimination, and correction of grammatical errors. In addition, a dimensionality reduction was 
performed by eliminating attributes or questions with low variability, which, in this case, was applied to questions with IDs $7,19,21$, and 28 , considering a threshold of $20 \%$ of different answers.

\section{Codification}

Some questions had the possibility of choosing or specifying more than one answer; as a consequence, a transformation was carried out by one-hot codification, which consists of separating the values of each answer considering each of them as a different binary attribute, where 1 indicates the presence of the value in the response of an interviewee, and 0 represents the absence of the value. For example, in the question, "what skills do you consider necessary to develop or improve mentoring?" six answer options were possible: leadership, organization, empathy, motivation, communication, and other; each one of these were transformed into six attributes as shown in Table 7. This step was applied to the multiple categorical questions with IDs 6, 18, 20,26, and 27. It is important to mention that Questions 18 and 20 had an open value range, so the number of coded attributes corresponds to the single answer options indicated by the interviewees, with a total of 60 and 38 attributes, respectively.

Table 7. Example of codification for a multiple categorical question.

\begin{tabular}{cccccccc}
\hline Interviewee & Leadership & Organization & Empathy & Motivation & Communication & Other \\
\hline 1 & 1 & 0 & 1 & 1 & 1 & 1 & 1 \\
2 & 0 & 0 & 1 & 1 & $\ldots$ & 1 \\
3 & 1 & 1 & 1 & $\ldots$ & $\ldots$ & $\ldots$ \\
$\ldots$ & $\ldots$ & 1 & 1 & 0 & 0 & 0 \\
\hline
\end{tabular}

\section{Generalization}

This process consists of replacing low-level data with high-level data using a hierarchy of concepts [21] (pp. 117-119). In this work, the generalization of the corresponding answers to the questions with IDs 3,18 , and 20 was carried out, because these questions were an open option type, and their range of values was wide. Table 8 shows the number of initial and final values of this process for each of the questions and the final value range.

Table 8. Generalization of attributes with wide value range.

\begin{tabular}{cccc}
\hline Question Id & Unique Initial Answers & Generalized Answers & Value Range \\
\hline 3 & 21 & 10 & $\begin{array}{c}\text { Biomedical, computer science, education, } \\
\text { electronics, industrial, informatics, } \\
\text { nanotechnology, psychology, chemistry, robotics }\end{array}$ \\
\hline 18 & 60 & 10 & $\begin{array}{c}\text { Programming, business, marketing, design, } \\
\text { video editing, drafting, English, project } \\
\text { management, digital tools, other }\end{array}$ \\
\hline 20 & 38 & 10 & $\begin{array}{c}\text { Programming, business, marketing, design, } \\
\text { video editing, drafting, English, project } \\
\text { management, digital tools, other }\end{array}$ \\
\hline
\end{tabular}

\section{Transformation}

In order to perform the statistical and data-mining analyses, the transformation process was performed on the questions with IDs 8 to 17, consisting of converting the ordinal values to the numerical range, preserving the order, based on Equation (1).

$$
Z_{i}^{\prime}=\frac{z_{i}-1}{|Z|-1}
$$


where $Z=\{$ null $\rightarrow 1$, low $\rightarrow 2$, average $\rightarrow 3$, good $\rightarrow 4$, outstanding $\rightarrow 5\}$, i.e., $Z=\{1,2,3,4,5\}$ resulting in $Z^{\prime}=\{0,0.25,0.5,0.75,1\}$.

\subsection{Data Processing}

In order to analyze the different perspectives on the benefits of mentoring, several analyses were carried out using two different approaches: statistics and data mining, which are described below.

\subsubsection{Statistical Analysis}

Questions corresponding to general data (1 to 6), soft skills (8 to 17), and technical knowledge (18 and 20) sections were analyzed from a statistical perspective, and no extra processing was needed. The results of this analysis are shown in the following section.

\subsubsection{Data-Mining Analysis}

Three analyses were performed corresponding to the mentors' perceptions regarding: (a) as female role models, (b) the influence of mentoring on their reinforcement or closeness to STEM areas, and (c) their general perception of mentoring. Each of these is described as follows.

\section{(a) Role model perception}

This analysis was based on the following question: "why do you consider yourself a female role model?" Because the response was open-ended, we chose to implement a word cloud in order to graphically show those words that were most frequently used to describe the reasons for their consideration. For this purpose, all responses were considered as a bag of words. Subsequently, non-content words (such as articles, pro-names, etc.) were eliminated, and lemmatization of the remaining words was carried out to obtain the base form of the words-for example, the lemma of "studied" is the word "study." In addition, a manual cleaning process was performed by an expert. Finally, Jason Davies' program [22] was used for word-cloud image generation.

\section{(b) STEM perception}

Due to the fact that the Technovation Girls program is strongly related to STEM areas, and because all the mentors surveyed participated in this program, questions with IDs 24 and 25 were added to the questionnaire to analyze if being a mentor brings them closer to or reinforces their vocation in these areas. Additionally, for in-depth analysis and in order to automatically determine the characteristics related to female mentors who are attracted to STEM areas against those who are not, a classification model was generated using decision trees. A decision tree is a kind of map showing the criteria included in an algorithm to decide whether an instance or subject belongs to a class or another [21] (pp. 330-332). Specifically, in this case, the class was "STEM reinforcement" for mentors who expressed that mentoring brought them closer to or reinforced their vocation in STEM areas, and "no STEM reinforcement" for those that expressed the opposite; so, the decision tree allowed us to automatically find the characteristics or attributes that define both classes. To evaluate the performance of the generated model, the F1-score and the classification accuracy were used [21] (pp. 364-369).

For this purpose, two approaches were performed: in the first one, general data were considered as attributes (age, education level, professional area, years of mentoring, and hours spent in mentoring) and those related to Question 26 about the soft skills that they consider worked for them in their mentoring (commitment, motivation, organization, and communication); in the second case, only the attributes of soft skills were considered, removing those corresponding to general data. In both cases, the question with ID 24 was considering the class or target attribute. To obtain the decision trees, the Orange data-mining program [23] was used. 


\section{(c) General perception}

"Sentiment analysis aims to automatically uncover the underlying attitude that we hold towards an entity" [24]. Currently, sentiment analysis in text, also known as opinion mining, is used to evaluate customer satisfaction or to analyze the perception of a brand. In order to observe the general perception of the mentor's experience, a study based on sentiment analysis and taking into consideration Question 31 was performed. For this purpose, the following steps were applied: text preprocessing, English translation, and text categorization, as described below.

Text Preprocessing: In order to determine the positive or negative polarity of a text, all empty answers were eliminated; afterward, emoticons were eliminated, and punctuation marks were correctly formatted. If a comment contained several sentences, it was considered as part of the same answer, separated by a point.

English Translation: Given that the mentors' comments were written in Spanish and that many of the sentiment analysis tools are trained for the English language, a translation of the comments into English was applied. For this, the Google Translation tool was used [25], and a subsequent review by an expert was performed.

Text Categorization: In order to calculate the emotional polarity and to determine if the mentors' comments are positive, negative, or neutral, sentiment analysis was applied by the Text Analytics platform [26]. This tool uses deep learning methods for natural language processing; in general, each sentence is divided into tokens or words and represented as a tree structure. A pre-training learning model based on real user, product, and service feedback was used by the Text Analytics platform to obtain the final score.

\section{Results and Discussion}

The survey was applied to mentors of the Technovation Girls program obtaining 43 answers, and the results are presented according to the different sections of the survey.

\subsection{General Data}

Figure 1 shows the age distribution of the 43 mentors in four equal-width bins, with a width equal to 7 .

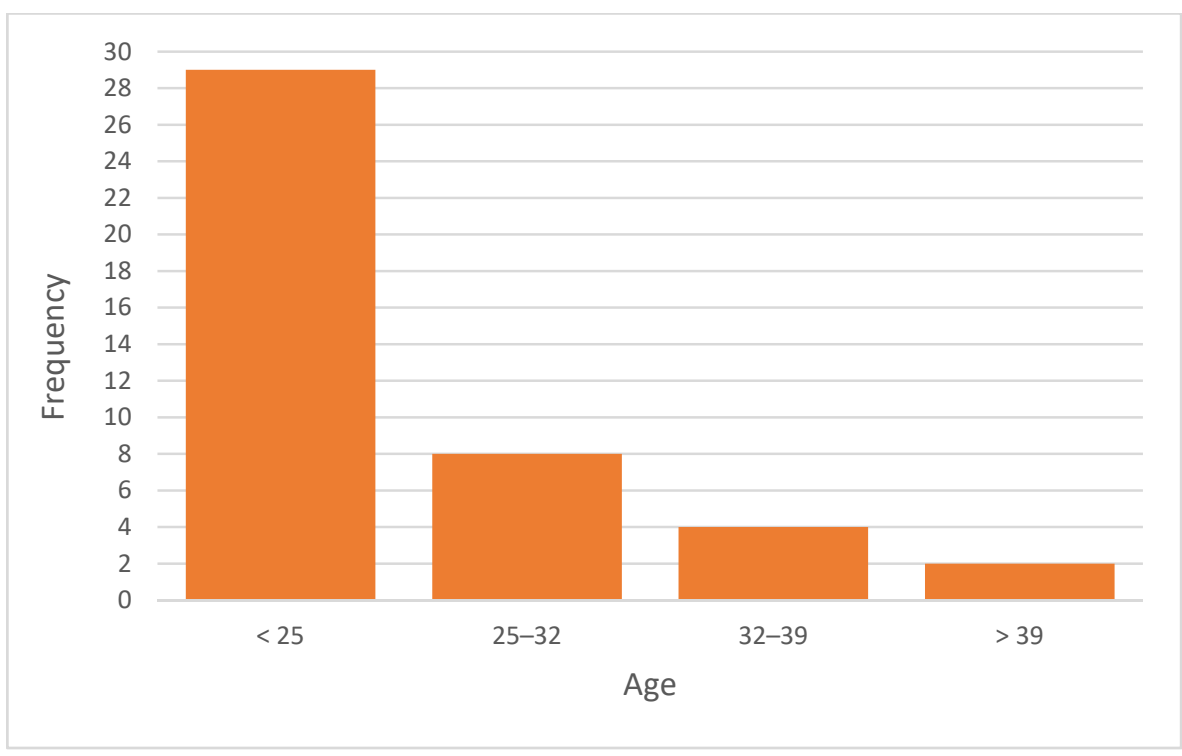

Figure 1. Age distribution of the 43 mentors.

The minimum age was 18 , and the maximum age is 46 . As can be observed, most of the mentors were under 25 years of age, which is because the program in which they participate as mentors is carried out at the University of Guadalajara, and the career students are constantly invited to participate. Therefore, most of the mentors' educational level was 
a bachelor's degree, with a frequency of 35, while for high school education, master's degrees, and doctorate degrees, it was 3,4 , and 1 , respectively.

Regarding how long they have been mentors, 27 of them expressed that they have only been participating for 1 year; 10 mentors have been participating for 2 years; 4 have participated for 3 years; and only 2 mentors have participated for 4 years.

The average hours spent mentoring was $5.6 \mathrm{~h}$; this is due to the fact that mentors must follow up with the teams' work during the week, and they also must attend the training workshops on Saturday.

Finally, related to the mentors' professional areas, and, as mentioned in the generalization section of the methodology, the careers were grouped into 10 professional areas, and their distribution is shown in Figure 2.

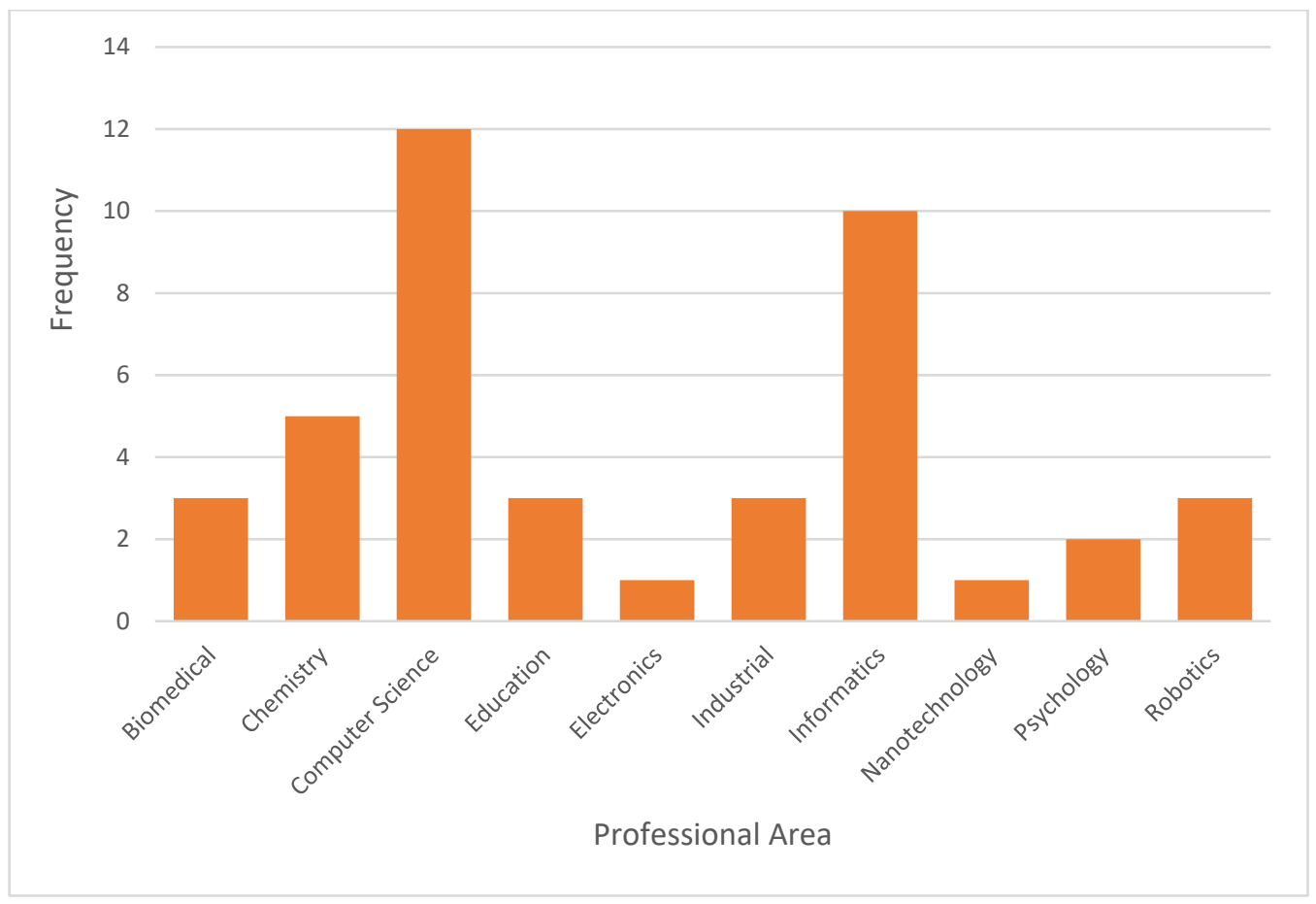

Figure 2. Distribution of the 43 mentors according to their professional area.

As can be observed, most of the mentors have a background in computer science or informatics. This can be related to the main goal of the program in which the mentors participate, which is the developing of a mobile application; so, many of the students from these careers register to the mentoring program, due to the fact that they have the technical knowledge to provide advice to their teams in the programming part, and, although students from all careers are generally invited, there is a stronger promotion of the program in these areas.

\subsection{Soft Skills}

In terms of soft skills and with respect to the question with ID 6 ("what skills do you consider necessary to develop or improve mentoring?"), the corresponding results are shown in Figure 3, wherein general mentors considered that all soft skills are required for the mentoring process. 


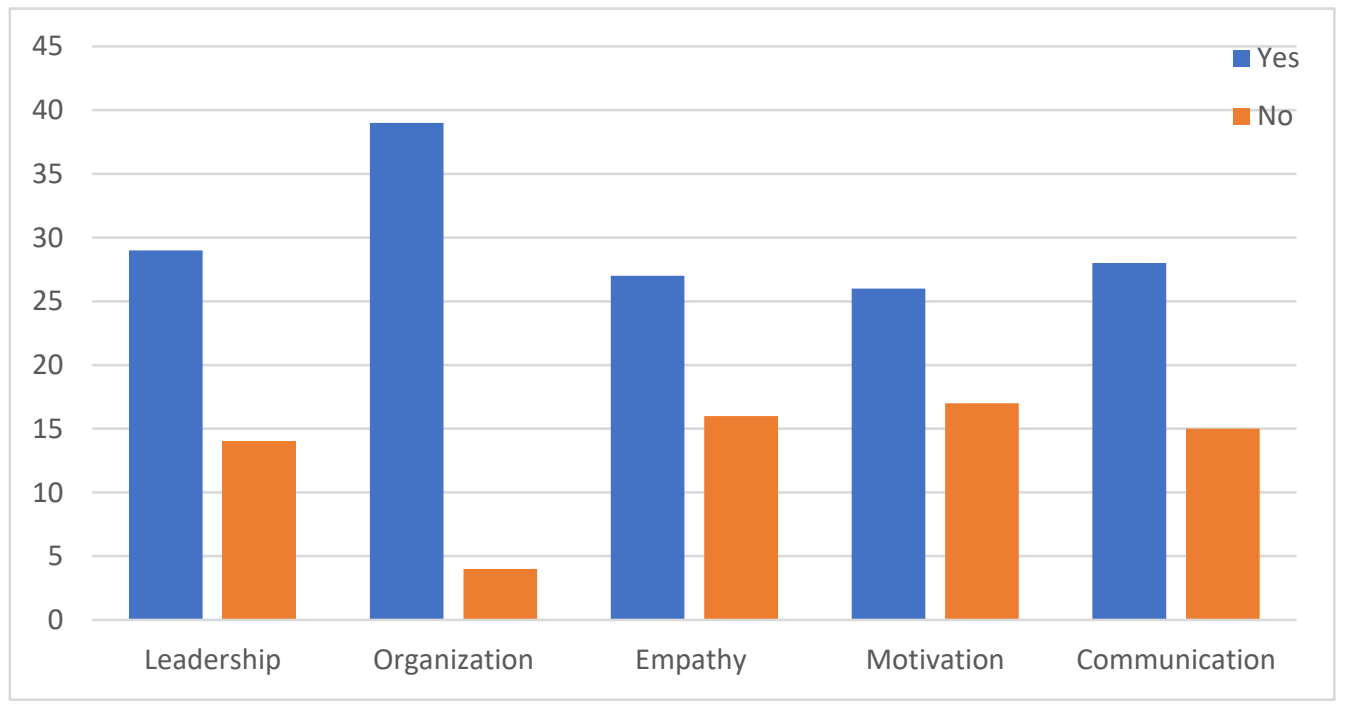

Figure 3. Soft skills required for mentoring according to the mentors' criteria.

It is important to note that the soft skill that is considered to be most needed by mentors is "organization" with 39 positive responses, and the skill that is considered least necessary is "motivation" with 17 negative responses. The latter result is interesting because several authors mention that motivation is an important factor in mentoring $[27,28]$, and it is also fundamental to mentors' development [29]; at the same time, motivation is one of the most difficult elements to maintain in the learning process of students [30].

In the study "the role of the mentor in a university mentoring process" [31], it is explained that both the mentor and the mentee are benefited from a mentoring process, but it is the mentor as the one who benefits the most in terms of skills development. In order to identify the benefits acquired regarding soft skills, the mentors participating in the study were asked if they considered having acquired or improved any of the soft skills by being a mentor (Question 7), and all except one of the mentors considered that they had. The person who answered "no" was the oldest, which may mean that she has previous knowledge and experience in her life, so she does not consider that she acquired new skills or improved existing ones.

In this regard, to analyze the soft-skill progress in mentoring, the answers to Questions 8 to 17 , already transformed into numerical values, were considered (see "Transformation" in Section 2.4 Part 4). Most of the mentors showed progress in at least one skill, and only three of them considered that they did not make progress in any ability. Figure 4 shows the organization and motivation level in which the mentors considered themselves to be at the beginning of the mentoring (blue color) and the level in which they considered themselves at the end of the mentoring (red color). This pair of skills was selected based on the results related to necessary skills considered by the mentors (see Figure 3), where organization and motivation skills were selected as the most and the least required, respectively. It is important to mention that in order to better appreciate the points' distribution, Figure 4 presents a $1 \%$ dispersion of the data. Based on these results, it can be observed that for both organization and motivation, there is a positive displacement in the data, i.e., mentors consider that, in general, they improved these two skills. Specifically, $67 \%$ of the interviewees considered an increase in their organization level, while $72 \%$ expressed an increase in their motivation level. 


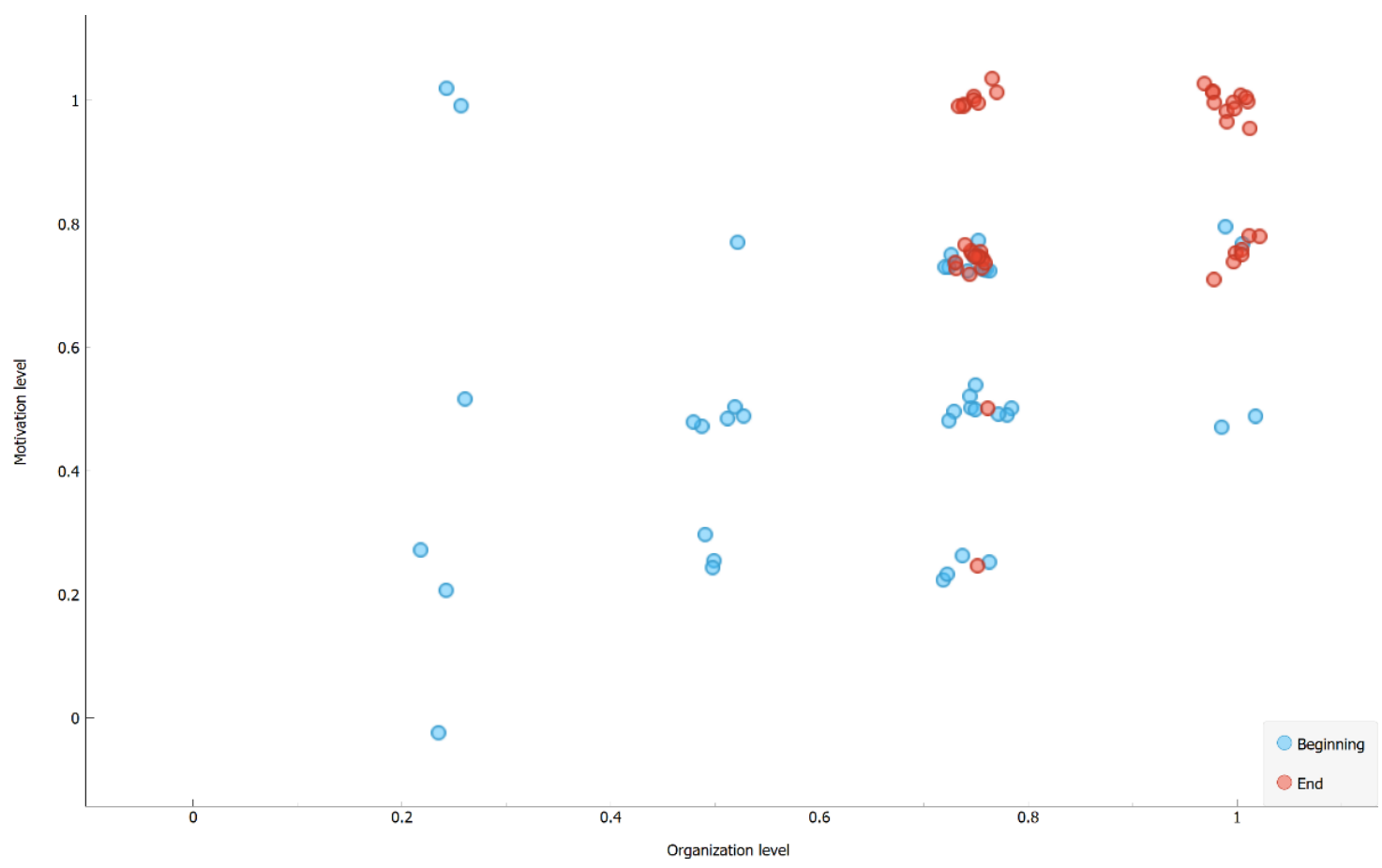

Figure 4. Scatter plot of organization against motivation level at the beginning and end of the mentoring.

In addition, Figure 5 shows the scatter plot of the initial and final level of the mentors with respect to leadership and empathy skills. These two skills showed the best distribution according to the average classification accuracy determined by the Orange data-mining tool [23]. Analyzing individually those skills, $48 \%$ of the mentors considered that they improved their empathy level, while 52\% remained at the same level; as for leadership, 77\% of the interviewee considered that they increased their leadership level, and 23\% remained at the same level.

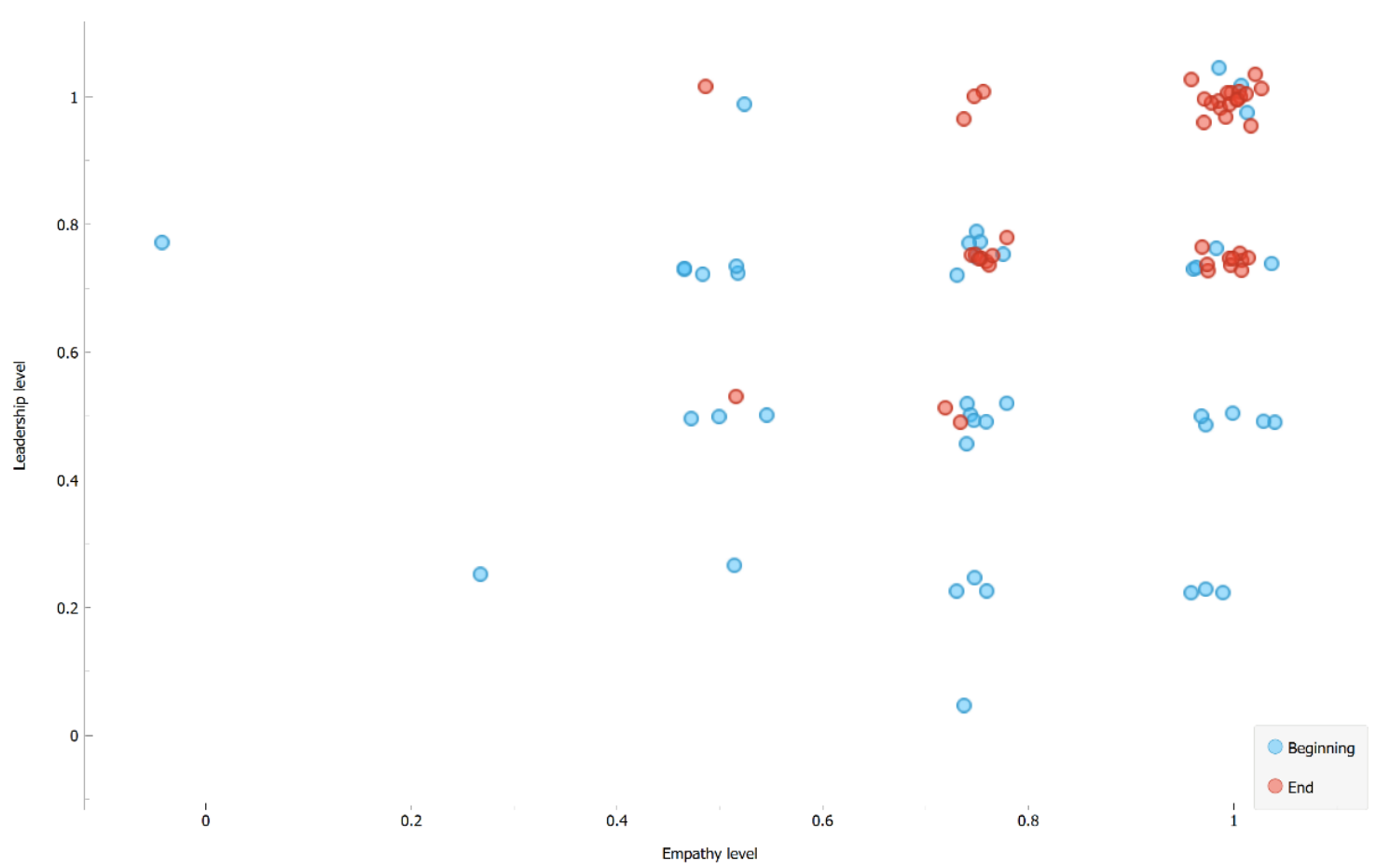

Figure 5. Scatter plot of empathy against leadership level at the beginning and end of the mentoring. 
Finally, with regard to communication skills, $65 \%$ of the mentors considered that they had an increase in this skill, while the rest remained at the same level.

Overall, the results show that four out of five soft skills increased in level, which is consistent with several authors who mention that these skills are one of the benefits acquired when mentoring [17-19], and mentoring is one of the best ways to acquire these [32]. With regard to empathy, which is the only skill that the mentors considered not to increase in level, this result is interesting because [33] mentions that more empathetic mentors tend to be more fulfilled with their mentoring. It should be noted that the starting empathy level of the mentors was high: $72 \%$ of them indicated a good or very good level at the beginning of their mentoring, which suggests that the progress level that they may have obtained during the mentoring could be not so noticeable.

\subsection{Technical Knowledge}

Not only are soft skills a benefit for mentors but several studies also mention that mentoring has a direct or indirect influence on the professional development of the participants $[34,35]$. In order to confirm it, Figure 6 shows the results obtained for the questions with IDs 18 and 20, where the interviewees stated which technical knowledge is necessary for mentoring and which is acquired through mentoring. It can be observed that mentors considered most of the technical knowledge related to the mentoring program to be acquirable during mentoring. However, in general, they had the perception that more knowledge is needed than acquired, which could be due to the majority of mentors belonging to a professional area related to such knowledge. That is, as mentioned above (see Figure 2), most of the mentors are related to the computer or informatics area, which makes them have knowledge related to programming, project management, and digital tools, so it is possible they did not perceive having acquired this knowledge.

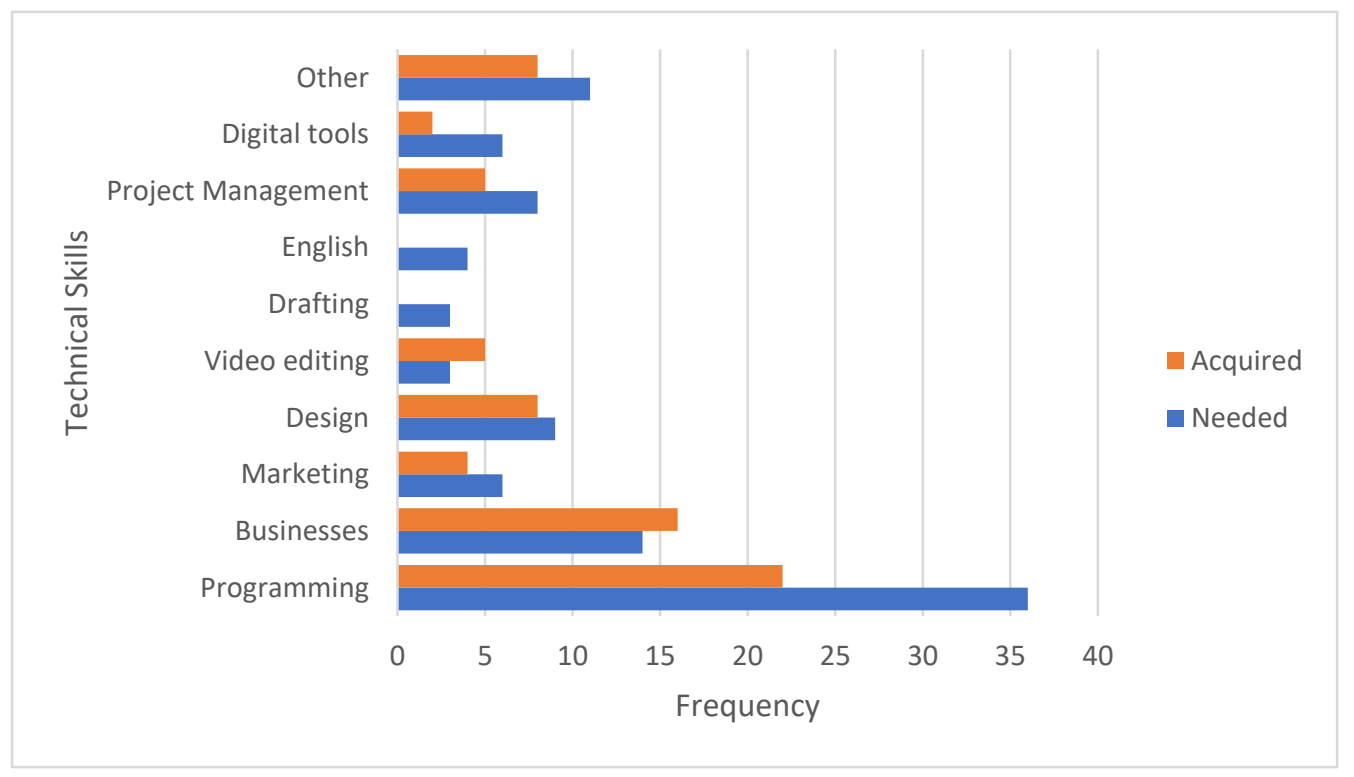

Figure 6. Technical skills that are considered necessary and acquired by the mentors.

Another interesting point, and to some extent anticipated, is that most of the interviewees believe that programming is required in mentoring; this is because the main goal of Technovation Girls is for teams to develop a mobile application. In addition, it is important to note that, even when Technovation Girls was performed in the electronic format last season, and most of the interviewee mentors provided this type of mentoring, only some of them considered it necessary to have knowledge in digital tools.

On the other hand, it is noticeable that in terms of video editing and businesses, the mentors stated that the knowledge acquired was greater than what they considered 
necessary. This could also be related to the professional area of the interviewees and the mentoring program goal, since the program also has a strong focus on the monetization of the project, which involves both marketing and businesses, and the mentors are trained to learn about these areas, even when they do not belong to these areas.

Finally, it can be observed that English and drafting skills are necessary but not acquired during the program. This is an important point for reinforcement during the mentoring preparation process.

\subsection{Role Model Perception}

To analyze the mentors' perceptions of themselves as female role models, Questions 21 to 22 were taken into account and followed the methodology of Section 2.5.2.; 88\% of the interviewees stated that they considered themselves to be female role models. Some of the most frequent characteristics attributed to being such were those related to the ability to motivate the mentee, dedication, effort, and passion, among others, as shown in the following word cloud (Figure 7), which allowed us to observe the recurrence in the answers of the participants and establish them as premises for the construction and reinforcement of the relationship and identification between the mentor and the mentee (role model) [11].

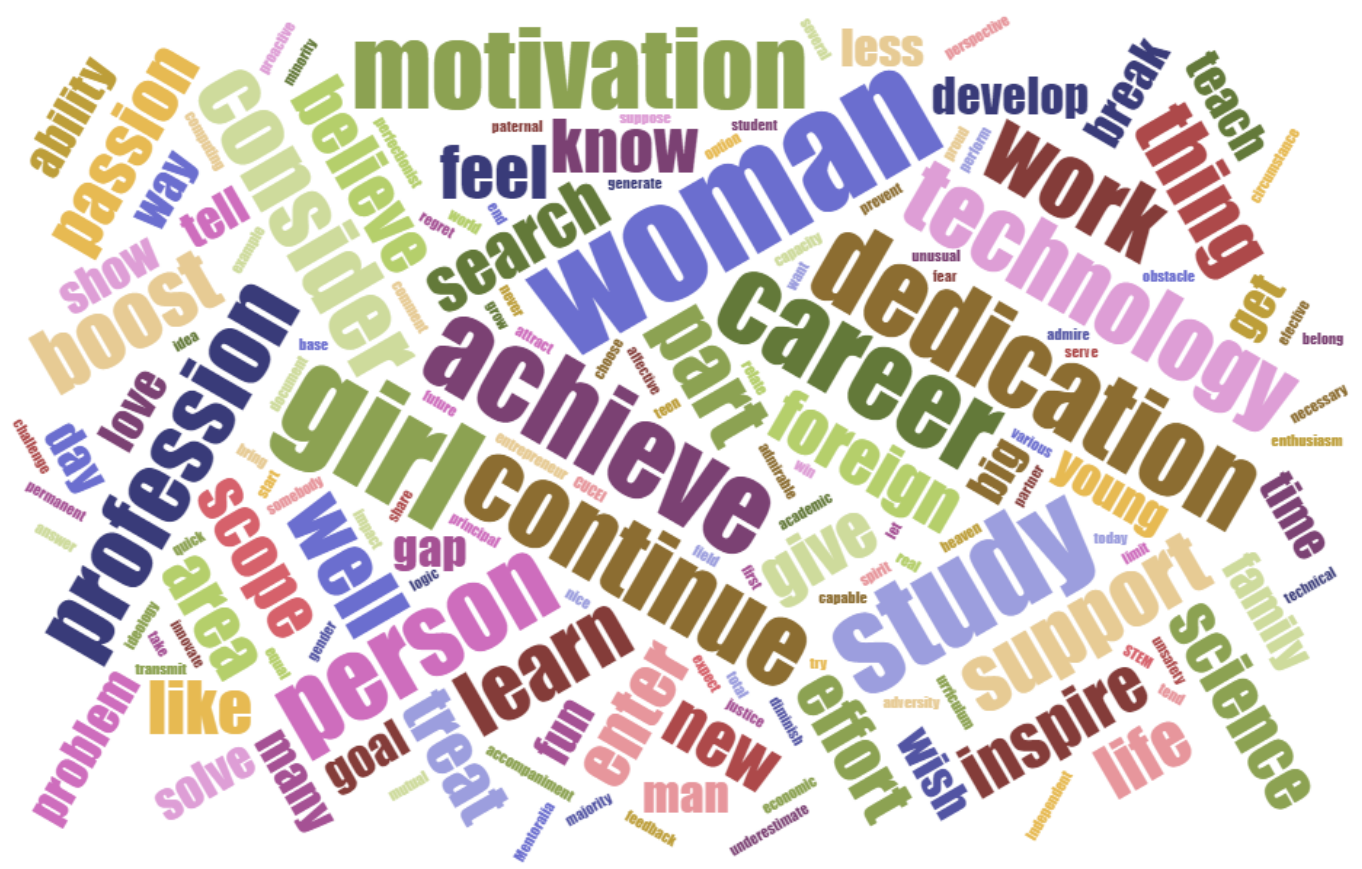

Figure 7. Words used by the mentors to describe themselves as female role models.

On the other hand, the $12 \%$ remaining considered personal motivation and insecurity as the factors that prevented them from being a female role model. This result may be related to the fact the women have a perception of lower self-efficiency and less effective personalities than men, even in stereotypically feminine careers [36]. However, this minority maintains to have benefited from mentoring, shaping skills they consider necessary to be a female role model.

\subsection{STEM Perception}

As mentioned in the "Materials and Methods" section, a data-mining analysis was performed to automatically determine the characteristics of female mentors whose mentoring attracted them to STEM areas or who perceived that mentoring reinforced their vocation in these areas. Figure 8 shows the decision tree generated for classification considering as attributes the general data and the soft skills that the mentors applied during their mentoring; this model presented an F1-score of 75\% and a classification accuracy of $63 \%$. 


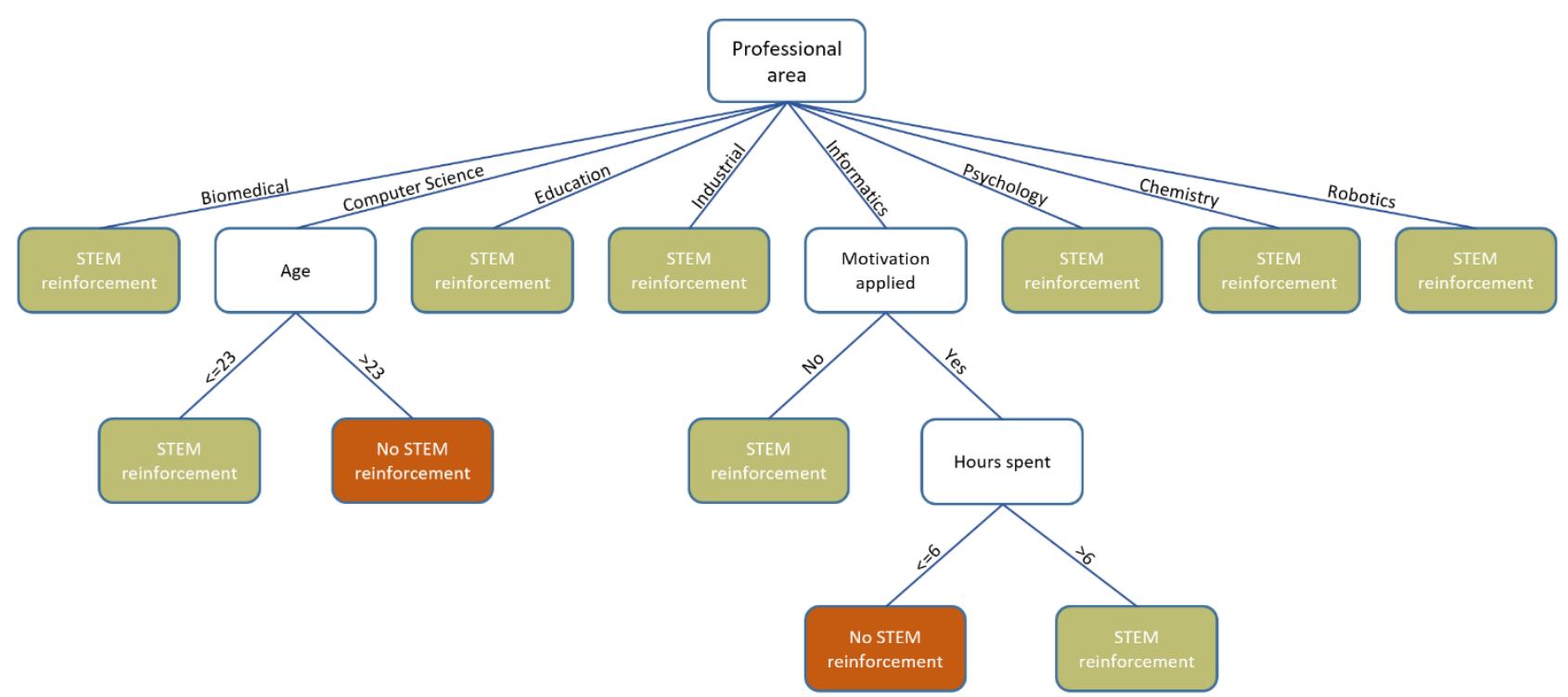

Figure 8. Classification model generated using decision trees, considering general data and soft skills applied by the mentors.

As can be observed in Figure 8, the professional area was the most important characteristic considered by the generated model to reinforcement or approach to STEM areas; mentors related to professional areas such as biomedicine, education, psychology, robotics, industry, and chemistry reported having a greater approach to STEM areas. On the other hand, in the cases of mentors related to computer science and informatics, other factors or characteristics such as applied motivation, age, and spent hours intervened. These results are interesting because they show that there is a relationship between the profile of the mentoring program and the mentors' professional area, and this, in turn, influences whether they feel attracted to or reinforce their STEM vocation. That is, the program in which the mentors participate is closely linked to the areas of programming and entrepreneurship, and the generated model shows that mentors outside these areas are attracted to or reinforce their STEM vocation; this could be because during the program the mentors learn new and challenging things, generating motivation and at the same time interest in them. On the other hand, with respect to mentors related to the area of the mentoring program, the model shows it is necessary to take into account other factors-for example, the younger computer science mentors (less or equal to 23 years old) reinforce their vocation, while the older ones do not perceive a vocation reinforcement. This result is consistent with what is presented in [37], which mentions that young mentors obtain a better perspective of STEM areas and what they can achieve.

The results of the model in Figure 8 focused mainly on the professional area of mentors, given that several authors related mentoring to soft skills [17-19], and there do not appear to be any state-of-the-art studies that consider the professional area as an important factor. The second analysis was performed by eliminating the general data attributes and retaining only the soft skills that the mentors believe worked for them in their mentoring. Figure 9 shows the classification model generated for this second analysis, with an F1-score of 79\% and a classification accuracy of $65 \%$. Based on the decision tree shown in Figure 9, it can be observed that motivation, commitment, and organization are the main factors for mentors to approach or strengthen their vocation in STEM areas. Therefore, these results show soft skills are not only an acquired benefit by the mentors [38] but they also bring them closer to the mentoring program, which in this case is closely linked to STEM areas. 


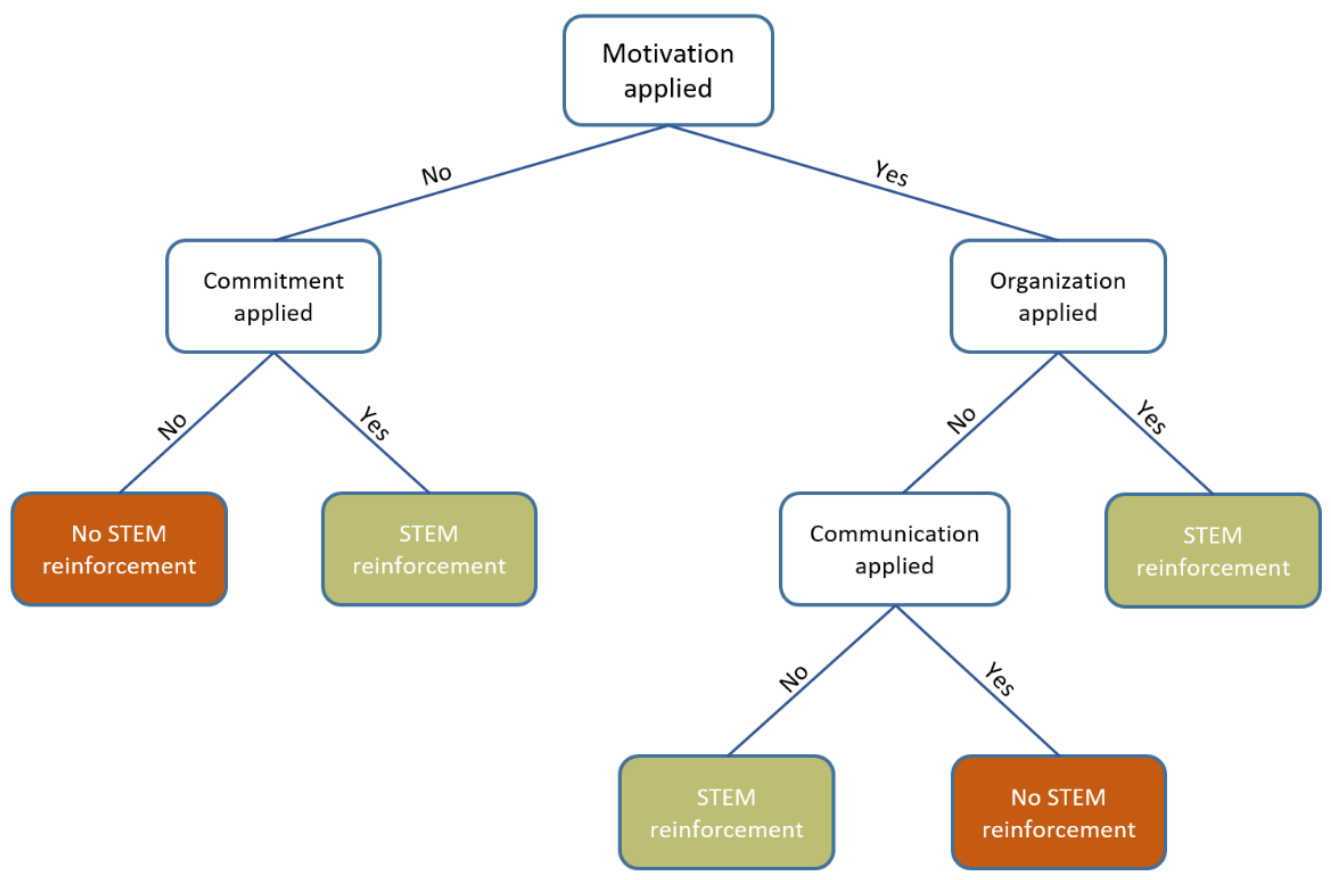

Figure 9. Classification model generated using decision trees, considering the soft skills applied by the mentors.

\subsection{General Perception}

In order to identify the general perception of the mentors regarding the benefits obtained and their experience within the mentoring program, two analyses were carried out: (a) the first from a qualitative perspective, considering the questions with IDs 29 and 30 corresponding to the benefits and impact of mentoring and (b) the second from a quantitative perspective, considering the question with ID 31 corresponding to the experience of the mentors.

Regarding the first approach, the analysis of the answers allowed to identify that some of the benefits related to the mentors of Technovation Girls program were the opportunity of reviewing some conceptual knowledge acquired before, the chance to develop interest and encourage young girls to study a STEM career, and also the near and trusting relationship accomplished with the mentees. These findings are in line with the findings of Colvin et al. [39], Ehrich et al. [40], and Kalpazidou et al. [41] who studied, among others, the benefits of peer-mentoring relationships in higher education. Interestingly, the mentors also related other benefits like the development of soft skills such as empathy and sociability, personal satisfaction, the improvement of leading, and the discovery of themselves as role models for other girls.

On the other hand, related to the second approach, processing based on sentiment analysis was applied in order to determine the emotional charge or polarity expressed in the final comments of the questionnaire (see Section 2.5.2 Part c). Table 9 presents the sentiment score and magnitude for each comment; because this question was optional, only 26 mentors answered. The sentiment of each comment in Table 9 was categorized according to the following: negative $([-1,-0.25])$, neutral $([-0.25,+0.25])$, and positive $([+0.25,1])$. The magnitude is the volume of sentiment expressed regardless of sentiment polarity, and it can be used to detect the strength of emotions or fine-tune sentiment polarity. It ranges from 0 to $\infty$.

Figure 10 shows the frequency distribution of the comments according to the score range. From the results obtained with the sentiment analysis, it can be observed the most of the mentors expressed positively their experience in the mentoring program. 
Table 9. Sentiment scores and magnitude, obtained from the mentors' comments about their experience in the mentoring program.

\begin{tabular}{|c|c|c|c|c|c|c|c|}
\hline Comment Id & Sentiment & $\begin{array}{l}\text { Sentiment } \\
\text { Score }\end{array}$ & Magnitude & Comment Id & Sentiment & $\begin{array}{l}\text { Sentiment } \\
\text { Score }\end{array}$ & Magnitude \\
\hline 1 & Positive & 0.663 & 0.83 & 14 & Positive & 1 & 0.999 \\
\hline 2 & Negative & -0.491 & 0.616 & 15 & Neutral & 0.167 & 0.33 \\
\hline 3 & Positive & 0.586 & 0.672 & 16 & Positive & 0.749 & 0.998 \\
\hline 4 & Positive & 0.749 & 0.998 & 17 & Positive & 0.619 & 0.738 \\
\hline 5 & Neutral & 0.143 & 0.429 & 18 & Positive & 0.64 & 0.835 \\
\hline 6 & Neutral & 0.123 & 0.506 & 19 & Neutral & 0.16 & 0.362 \\
\hline 7 & Positive & 0.61 & 0.737 & 20 & Positive & 0.55 & 0.648 \\
\hline 8 & Neutral & 0.169 & 0.323 & 21 & Positive & 0.644 & 0.814 \\
\hline 9 & Neutral & 0.217 & 0.131 & 22 & Negative & -0.548 & 0.633 \\
\hline 10 & Positive & 0.619 & 0.737 & 23 & Positive & 0.69 & 0.885 \\
\hline 11 & Positive & 0.697 & 0.897 & 24 & Neutral & 0.147 & 0.413 \\
\hline 12 & Positive & 0.64 & 0.835 & 25 & Positive & 0.684 & 0.872 \\
\hline 13 & Neutral & 0.138 & 0.448 & 26 & Neutral & 0.160 & 0.36 \\
\hline
\end{tabular}

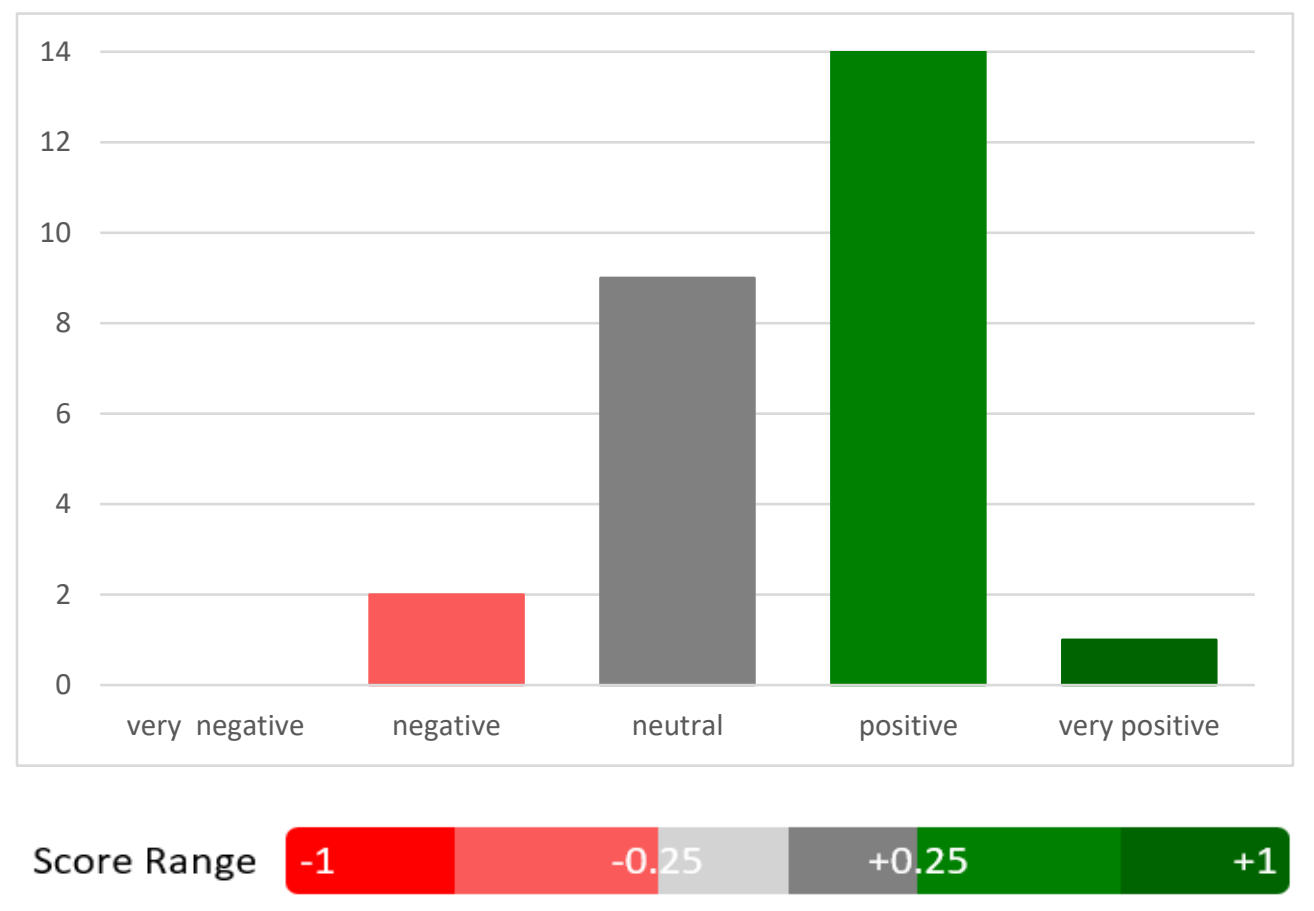

Figure 10. Mentors' comments about their experience, distributed by emotional polarity.

\section{Conclusions}

We performed quantitative and qualitative analyses of the benefits of young women's mentors in STEM programs. The study was done through data-mining techniques, identifying the following main benefits acquired by the mentors as part of voluntary peer accompaniment activities: the development of "soft skills" (like leadership, motivation, organization, and empathy) and the acquisition of multidisciplinary knowledge. In both cases, we conclude that both benefits extend beyond the mentoring period and strengthen the mentors' identity in their professional training areas.

For our analyses, the novel application of quantitative tools to study benefits, perceptions, and feelings related to mentoring was essential, contributing to a general panorama of the problem (namely, the lack of more women in STEM areas) and its possible solutions.

Firstly, concerning motivation skill, the data showed that the mentors do not consciously perceive it as necessary for the optimal development of mentoring. However, 
indirectly and through a word-cloud analysis, the mentors placed motivation as a priority skill that reinforces the empathetic approximation to girls and young women in STEM areas.

On the other hand, through our qualitative analysis, we recognized that the lack of motivation is related to the reluctance of the mentors to identify themselves as role models. In this sense, it is necessary to reinforce motivation as a means of empowerment so that mentors are recognized as female role models capable of inspiring new generations of women to join STEM areas and thus reducing the gender gap.

Based on the sentiment analysis focused on the general perception of mentoring, it is possible to conclude that the mentors' experience is mostly positive, which could be a consequence of the received benefits.

Finally, it is worth mentioning that this work presented a novel application of data mining and sentiment analysis to analyze quantitatively the benefits, perception, and STEM reinforcement related to mentoring.

Author Contributions: Conceptualization, S.T.-R. and C.N.-C.; methodology, S.T.-R., C.N.-C., N.S.F.-R., L.A.P.-C., C.C.-C., P.d.R.R.-V. and V.M.R.-B.; software, S.T.-R. and P.d.R.R.-V.; validation, C.N.-C. and S.T.-R.; formal analysis, S.T.-R., C.N.-C., N.S.F.-R., L.A.P.-C., C.C.-C., P.d.R.R.-V. and V.M.R.-B.; investigation, C.N.-C., N.S.F.-R. and S.T.-R.; resources, N.S.F.-R.; data curation, C.C.-C. and P.d.R.R.-V.; writing-original draft preparation, S.T.-R., C.N.-C., N.S.F.-R., L.A.P.-C., C.C.-C., P.d.R.R.-V. and V.M.R.-B.; writing-review and editing, S.T.-R., C.N.-C., N.S.F.-R. and L.A.P.-C.; visualization, L.A.P.-C. and C.C.-C.; supervision, S.T.-R. and V.M.R.-B. All authors have read and agreed to the published version of the manuscript.

Funding: This research received no external funding.

Institutional Review Board Statement: Not applicable.

Informed Consent Statement: Not applicable.

Data Availability Statement: Not applicable.

Acknowledgments: The authors acknowledge the mentors of the Technovation Girls.

Conflicts of Interest: The authors declare no conflict of interest.

\section{References}

1. University of Reading. Mentoring: Definitions and Principles. Available online: https://www.reading.ac.uk/engageinmentoring/ what-is-mentoring/eim-definitions.aspx (accessed on 21 October 2021).

2. Sands, R.G.; Parson, L.A.; Duane, J. Faculty Mentoring Faculty in a Public University. J. High. Educ. 1991, 62, 174-193. [CrossRef]

3. Sambunjak, D.; Straus, S.E.; Marušić, A. Mentoring in academic medicine: A systematic review. JAMA 2006, 296, 1103-1115. [CrossRef] [PubMed]

4. Farrell, S.E.; Digioia, N.M.; Broderick, K.B.; Coates, W.C. Mentoring for clinician-educators. Acad. Emerg. Med. 2004, 11, 1346-1350. [CrossRef]

5. Beltman, S.; Schaeben, M. Institution-wide peer mentoring: Benefits for mentors. Int. J. First Year High. Educ. 2012, 3, 33-44. [CrossRef]

6. Mullen, C.A.; Klimaitis, C.C. Defining mentoring: A literature review of issues, types, and applications. Ann. N. Y. Acad. Sci. 2019, 1483, 19-35. [CrossRef]

7. Jones, R.; Brown, D. The Mentoring Relationship as a Complex Adaptive System: Finding a Model for Our Experience. Mentor. Tutoring: Partnersh. Learn. 2011, 19, 401-418. [CrossRef]

8. Mullen, C.A.; Kennedy, C.S. It Takes a Village to Raise New Faculty: Implementing Triangular Mentoring Relationships. Fla. Educ. Leadersh. 2007, 7, 24-27.

9. Tong, C.; Kram, K. The Efficacy of Mentoring-the Benefits for Mentees, Mentors, and Organizations. In The Wiley-Blackwell Handbook of the Psychology of Coaching and Mentoring; John Wiley and Sons: Hoboken, NJ, USA, 2012; pp. 217-242. [CrossRef]

10. Ibarra, H. Provisional Selves: Experimenting with Image and Identity in Professional Adaptation. Adm. Sci. Q. 1999, 44, 764-791. [CrossRef]

11. Gibson, D.E. Role models in career development: New directions for theory and research. J. Vocat. Behav. 2004, 65, 134-156. [CrossRef] 
12. Breda, T.; Grenet, J.; Monnet, M.; Van Effenterre, C. Do Female Role Models Reduce the Gender Gap in Science? Evidence from French High Schools. IZA DP. 2020. Available online: https:/ /halshs.archives-ouvertes.fr/halshs-01713068 (accessed on 22 November 2021).

13. Lockwood, P.; Kunda, Z. Superstars and me: Predicting the impact of role models on the self. J. Personal. Soc. Psychol. 1997, 73, 91-103. [CrossRef]

14. Technovation Girls. Available online: https://technovationchallenge.org/ (accessed on 18 October 2021).

15. Bettinger, E.P.; Long, B.T. Do Faculty Serve as Role Models? The Impact of Instructor Gender on Female Students. Am. Econ. Rev. 2005, 95, 152-157. [CrossRef]

16. Carrell, S.E.; Page, M.E.; West, J.E. Sex and Science: How Professor Gender Perpetuates the Gender Gap. Q. J. Econ. 2010, 125, 1101-1144. [CrossRef]

17. Krishna, R.; Mangadu Paramasivam, G. Do mentors learn by mentoring others? Int. J. Mentor. Coach. Educ. 2012, 1, 205-217. [CrossRef]

18. Lluch, A.M.; Lluch, C.; Arregui, M.; Jiménez, E.; Giner-Tarrida, L. Peer mentoring as a tool for developing soft skills in clinical practice: A 3-year study. Dent. J. 2021, 9, 57. [CrossRef]

19. Murray, K.A.; Stollar, M.; McClellan, R.; King, J.; Hattey, J.A. A Systematic Map and Scoping Review of Soft Skill Assessment Instruments for College Students and Peer Mentoring Programs. Nacta J. 2018, 62, 267-274.

20. Torres-Ramos, S.; Retamoza-Vega, P.D.R.; Fajardo-Robledo, N.S.; Neri-Cortés, C.; Rodríguez-Betancourtt, V.M.; Pérez-Carrillo, L.A. Towards increasing of STEM-women professionals by implementing projects that reduce the gender gap: A study case in Universidad de Guadalajara. In Proceedings of the Eighth International Conference on Technological Ecosystems for Enhancing Multiculturality, Salamanca, Spain, 21-23 October 2020; García-Peñalvo, F.J., Ed.; ACM: New York, NY, USA, 2020 ; pp. 166-172. [CrossRef]

21. Han, J.; Kamber, M.; Pei, J. Data Mining: Concepts and Techniques, 3rd ed.; Elsevier: Amsterdam, The Netherlands, 2011.

22. Word Cloud Generator-Jason Davies. Available online: https://www.jasondavies.com/wordcloud/ (accessed on 29 September 2021).

23. Demšar, J.; Curk, T.; Erjavec, A.; Gorup, C.; Hočevar, T.; Milutinovič, M.; Možina, M.; Polajnar, M.; Toplak, M.; Starič, A.; et al. Orange: Data mining toolbox in Python. J. Mach. Learn. Res. 2013, 14, 2349-2353.

24. Soleymani, M.; Garcia, D.; Jou, B.; Schuller, B.; Chang, S.F.; Pantic, M. A survey of multimodal sentiment analysis. Image Vis. Comput. 2017, 65, 3-14. [CrossRef]

25. Google Translator. Available online: https://translate.google.com.mx/?hl=es (accessed on 6 October 2021).

26. Text Analytics Platform. Available online: https://text2data.com/ (accessed on 6 October 2021).

27. Elaveetil Santhosh, M.; Bhadra, D.J.; Saad, A.; Magdy, R.; Alkhair, S.; Ali, R.; Ehalwary, E.; Al-Thani, D. A Comparative UG Near-Peer Mentoring Model, for Motivating School Students towards Innovations, during E-STEM Education-A Case Study of Qatar. 2021. Available online: https:/ / qspace.qu.edu.qa/handle/10576/24466 (accessed on 22 November 2021).

28. Peddy, S. Unidad de Conocimiento: El Mentoring. Available online: https://factorhuma.org/attachments_secure/article/8294/_ 1461378de534f2_mentoring_cast.pdf (accessed on 25 October 2021).

29. Zubairu, A.N.; Ngeme, F.; Olagoke, P.D. Mentoring and employee motivation as determinants of job productivity of library personnel in university libraries in Osun state. Libr. Philos. Pract. 2021. Available online: https://digitalcommons.unl.edu/ libphilprac/6193/ (accessed on 22 November 2021).

30. Azzahro, R.; Maghfiroh, A.; Indriastuti, N.R. Maintaining Students' Extrinsic Motivation in Online Learning: Teachers' Problem. In Proceedings of the International Conference of Education, Social, and Humanities (1ST INCESH), Web of Science, Ponorogo, Indonesia, 3 June 2021. [CrossRef]

31. Manzano, N.S.; Martín, A.C.; Sánchez, M.G.; Rísquez, A.; Suárez, M.O. El rol del mentor en un proceso de mentoría universitaria. Educ. XX1 2012, 15, 93-118. [CrossRef]

32. Ahmad, S.; Ameen, K.; Ullah, M. Modes of soft skills learning: A case of university information professionals' in Pakistan. Libr. Rev. 2017, 66, 711-725. [CrossRef]

33. Spencer, R.; Pryce, J.; Barry, J.; Walsh, J.; Basualdo-Delmonico, A. Deconstructing empathy: A qualitative examination of mentor perspective-taking and adaptability in youth mentoring relationships. Child. Youth Serv. Rev. 2020, 114, 105043. [CrossRef]

34. Poulsen, K. A New Way of Seeing Mentoring. Available online: https://kmpplus.com/wp-content/uploads/2014/02/A-newway.pdf (accessed on 25 October 2021).

35. Altonji, S.J.; Baños, J.H.; Harada, C.N. Perceived Benefits of a Peer Mentoring Program for First-Year Medical Students. Teach. Learn. Med. 2019, 31, 445-452. [CrossRef] [PubMed]

36. Vignera, M.M. El sexo y la Identidad de Género y su Relación con Variables Psicoeducativas en Estudiantes Universitarios. Ph.D. Thesis, Universitat d'Alacant-Universidad de Alicante, Alicante, Spain, 2019.

37. Anderson, M.K.; Anderson, R.J.; Tenenbaum, L.; Kuehn, E.D.; Brown, H.K.M.; Ramadorai, S.B.; Yourick, D. The Benefits of a Near-Peer Mentoring Experience on STEM Persistence in Education and Careers: A 2004-2015 Study. J. STEM Outreach 2019, 1, 1-11. [CrossRef]

38. Velasco, P.J.Q.; Domínguez, F.S.; Quintas, S.B.; Blanco, A.F. La mentoría entre iguales y el desarrollo de competencias. Mentor. Coach. 2010, 3, 71-85. 
39. Colvin, J.W.; Ashman, M. Roles, Risks, and Benefits of Peer Mentoring Relationships in Higher Education. Mentor. Tutoring: Partnersh. Learn. 2010, 18, 121-134. [CrossRef]

40. Ehrich, L.C.; Hansford, B.; Tennent, L. Formal Mentoring Programs in Education and Other Professions: A Review of the Literature. Educ. Adm. Q. 2004, 40, 518-540. [CrossRef]

41. Kalpazidou, E.S.; Thidemann, S.F. Benefits of Peer Mentoring to Mentors, Female Mentees and Higher Education Institutions. Mentor. Tutoring Partnersh. Learn. 2016, 24, 137-157. [CrossRef] 